\title{
A vibrational spectroscopic study of the phosphate mineral whiteite CaMn ${ }^{++} \mathrm{Mg}_{2} \mathrm{Al}_{2}\left(\mathrm{PO}_{4}\right)_{4}(\mathrm{OH})_{2} \cdot 8\left(\mathrm{H}_{2} \mathrm{O}\right)$
}

\author{
Ray L. Frost ${ }^{\mathrm{a}, *}$, Ricardo Scholz ${ }^{\mathrm{b}}$, Andrés López ${ }^{\mathrm{a}}$, Yunfei Xi ${ }^{\mathrm{a}}$

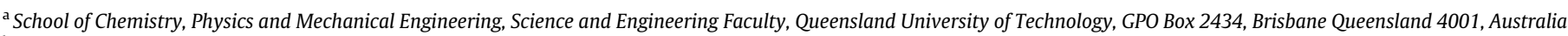 \\ ${ }^{\mathrm{b}}$ Geology Department, School of Mines, Federal University of Ouro Preto, Campus Morro do Cruzeiro, Ouro Preto, MG, 35,400-00, Brazil
}

\section{H I G H L I G H T S}

- Vibrational spectroscopy enables subtle details of the molecular structure of whiteite.

- Crystals of a pure phase from a Brazilian pegmatite were used.

- Raman and infrared bands are assigned to the vibrations of $\mathrm{PO}_{4}^{3-}$.

- A comparison is made with the vibrational spectra of wardite.

\section{G R A P H I C A L A B S T R A C T}

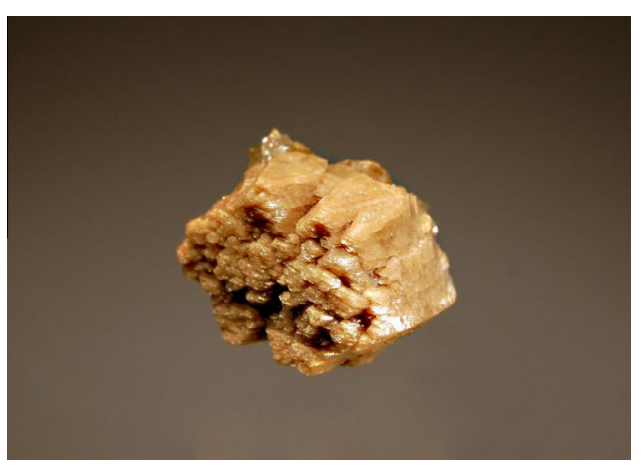

\begin{abstract}
A B S T R A C T
Vibrational spectroscopy enables subtle details of the molecular structure of whiteite to be determined. Single crystals of a pure phase from a Brazilian pegmatite were used. The infrared and Raman spectroscopy were applied to compare the molecular structure of whiteite with that of other phosphate minerals. The Raman spectrum of whiteite shows an intense band at $972 \mathrm{~cm}^{-1}$ assigned to the $v_{1} \mathrm{PO}_{4}^{3-}$ symmetric stretching vibrations. The low intensity Raman bands at 1076 and $1173 \mathrm{~cm}^{-1}$ are assigned to the $v_{3} \mathrm{PO}_{4}^{3-}$ antisymmetric stretching modes. The Raman bands at 1266, 1334 and $1368 \mathrm{~cm}^{-1}$ are assigned to AlOH deformation modes. The infrared band at $967 \mathrm{~cm}^{-1}$ is ascribed to the $\mathrm{PO}_{4}^{3-} v_{1}$ symmetric stretching vibrational mode. The infrared bands at 1024, 1072, 1089 and $1126 \mathrm{~cm}^{-1}$ are attributed to the $\mathrm{PO}_{4}^{3-} v_{3}$ antisymmetric stretching vibrations. Raman bands at 553,571 and $586 \mathrm{~cm}^{-1}$ are assigned to the $v_{4}$ out of plane bending modes of the $\mathrm{PO}_{4}^{3-}$ unit. Raman bands at 432, 457, 479 and $500 \mathrm{~cm}^{-1}$ are attributed to the $v_{2} \mathrm{PO}_{4}$ and $\mathrm{H}_{2} \mathrm{PO}_{4}$ bending modes. In the 2600 to $3800 \mathrm{~cm}^{-1}$ spectral range, Raman bands for whiteite are found 3426, 3496 and $3552 \mathrm{~cm}^{-1}$ are assigned to AlOH stretching vibrations. Broad infrared bands are also found at $3186 \mathrm{~cm}^{-1}$. Raman bands at 2939 and $3220 \mathrm{~cm}^{-1}$ are assigned to water stretching vibrations. Raman spectroscopy complimented with infrared spectroscopy has enabled aspects of the structure of whiteite to be ascertained and compared with that of other phosphate minerals.
\end{abstract}

() 2014 Elsevier B.V. All rights reserved.

\section{Introduction}

The mineral whiteite [1] is a phosphate mineral belonging to the jahnsite mineral group [2]. In the whiteite formulae, the symbols in brackets indicate the dominant atom in three distinct

\footnotetext{
* Corresponding author. Tel.: +61 73138 2407; fax: +61 731381804 .

E-mail address: r.frost@qut.edu.au (R.L. Frost).
}

structural positions, designated $\mathrm{X}, \mathrm{M}(1)$, and $\mathrm{M}(2)$, in that order; for instance, magnesium $\mathrm{Mg}$ is always the dominant atom in the $\mathrm{M}(2)$ position for all the whiteite minerals [3]. For whiteite, the $\mathrm{Al}>\mathrm{Fe}$ in the $\mathrm{M} 3$ position; if $\mathrm{Fe}>\mathrm{Al}$, then the mineral is jahnsite. Moore and Ito (1978) [4] proposed that the whiteite group, which has the general formula XM(1)M(2)rM(3);+-Jahnsite-(CaMnMn)(PO4)4(OH)r'HrO, is considered to consist of two series, with the $\mathrm{M}(3)$ site dominantly $\mathrm{Al} 3+$ for the whiteite series and $\mathrm{Fe} 3+$ for 
the jahnsite series. The interesting chemistry of both whiteite and jahnsite is these minerals contain multiple cations [5].

These two minerals form a continuous series of solid solutions [5]. Whiteite was named after John Sampson White Jr. (born 1933), associate curator of minerals at the Smithsonian Institute and founder, editor and publisher (1970-1982) of the Mineralogical Record. For example: whiteite-(CaFeMg), IMA1975-001, $\mathrm{CaFe}^{2+}$ $\mathrm{Mg}_{2} \mathrm{Al}_{2}\left(\mathrm{PO}_{4}\right)_{4}(\mathrm{OH})_{2} \cdot 8 \mathrm{H}_{2} \mathrm{O}$; Whiteite-(MnFeMg), IMA1978-A, $\mathrm{Mn}^{2+}$ $\mathrm{Fe}^{2+} \mathrm{Mg}_{2} \mathrm{Al}_{2}\left(\mathrm{PO}_{4}\right)_{4}(\mathrm{OH})_{2} \cdot 8 \mathrm{H}_{2} \mathrm{O}$; Whiteite-(CaMnMg), IMA1986-012, $\mathrm{CaMn}^{2+} \mathrm{Mg}_{2} \mathrm{Al}_{2}\left(\mathrm{PO}_{4}\right)_{4}(\mathrm{OH})_{2} \cdot 8 \mathrm{H}_{2} \mathrm{O}$; Rittmannite, $\mathrm{Mn}^{2+} \mathrm{Mn}^{2+} \mathrm{Fe}^{2+}{ }_{2}$ $\mathrm{Al}_{2}\left(\mathrm{PO}_{4}\right)_{4}(\mathrm{OH})_{2} \cdot 8 \mathrm{H}_{2} \mathrm{O}[4]$.

All members of the series belong to the monoclinic crystal system with point group $2 / \mathrm{m}$. Most sources give the space group as $\mathrm{P} 2{ }_{1} / \mathrm{a}$ for the $\mathrm{Ca}$ Fe rich member, which was the first of the series to be described, but Dana gives it as P2/a. The other members are variously described in different sources as having space groups $\mathrm{P} 2{ }_{1} / \mathrm{a}, \mathrm{P} 2 / \mathrm{a}$ or Pa. Whiteite minerals occur as aggregates of tabular crystals, or thick tabular canoe-shaped crystals [3]. Whiteite from Rapid Creek in the Yukon Canada [1,2,6,7], is often associated with deep blue lazulite crystals. Whiteite is invariably twinned, giving the crystals a pseudo-orthorhombic appearance and the cleavage is good to perfect. The mineral is also located Iron Monarch mine, Iron Knob, Middleback Range, Eyre Peninsula , South Australia and from the Glen Wills mining district, Omeo, East Gippsland, Victoria, Australia.

Raman spectroscopy has proven very useful for the study of minerals [8-14]. Indeed, Raman spectroscopy has proven most useful for the study of diagenetically related minerals where isomorphic substitution may occur as with wardite, cyrilovite and whiteite, as often occurs with minerals containing phosphate groups. This paper is a part of systematic studies of vibrational spectra of minerals of secondary origin. The objective of this research is to report the Raman and infrared spectra of whiteite and to relate the spectra to the molecular structure of the mineral.

\section{Experimental}

\section{Samples description and preparation}

The type locality for whiteite-(CaFeMg) and whiteite-(MnFeMg) is the Ilha claim, Taquaral, Itinga, Jequitinhonha valley, Minas Gerais, Brazil, and for whiteite-(CaMnMg) it is the Tip Top Mine (Tip Top pegmatite), Fourmile, Custer District, Custer County, Yukon, USA [6].

For the Brazilian whiteite, it is found in association with eosphorite, zanazziite, wardite, albite, quartz.

The sample was incorporated to the collection of the Geology Department of the Federal University of Ouro Preto, Minas Gerais, Brazil, with sample code SAC-018. The sample was gently crushed and the associated minerals were removed under a stereomicroscope Leica MZ4. The whiteite sample was phase analyzed by $\mathrm{X}$-ray diffraction. Scanning electron microscopy (SEM) in the EDS mode was applied to support the mineral characterization.

Wardite originated from Lavra Da Ilha, Minas Gerais, Brazil. Details of this mineral have been published (page 643) [15].

\section{Raman spectroscopy}

Crystals of whiteite were placed on a polished metal surface on the stage of an Olympus BHSM microscope, which is equipped with $10 \times, 20 \times$, and $50 \times$ objectives. The microscope is part of a Renishaw 1000 Raman microscope system, which also includes a monochromator, a filter system and a CCD detector (1024 pixels). The Raman spectra were excited by a Spectra-Physics model 127 He-Ne laser producing highly polarised light at $633 \mathrm{~nm}$ and collected at a nominal resolution of $2 \mathrm{~cm}^{-1}$ and a precision of $\pm 1 \mathrm{~cm}^{-1}$ in the range between 200 and $4000 \mathrm{~cm}^{-1}$. Repeated acquisitions on the crystals using the highest magnification $(50 \times)$ were accumulated to improve the signal to noise ratio of the spectra. Spectra were calibrated using the $520.5 \mathrm{~cm}^{-1}$ line of a silicon wafer. Previous studies by the authors provide more details of the experimental technique. Alignment of all crystals in a similar orientation has been attempted and achieved. However, differences in intensity may be observed due to minor differences in the crystal orientation.

\section{Infrared spectroscopy}

Infrared spectra were obtained using a Nicolet Nexus 870 FTIR spectrometer with a smart endurance single bounce diamond ATR cell. Spectra over the $4000-525 \mathrm{~cm}^{-1}$ range were obtained by the co-addition of 128 scans with a resolution of $4 \mathrm{~cm}^{-1}$ and a mirror velocity of $0.6329 \mathrm{~cm} / \mathrm{s}$. Spectra were co-added to improve the signal to noise ratio.

Spectral manipulation such as baseline correction/adjustment and smoothing were performed using the Spectracalc software package GRAMS (Galactic Industries Corporation, NH, USA). Band component analysis was undertaken using the Jandel 'Peakfit' software package that enabled the type of fitting function to be selected and allows specific parameters to be fixed or varied accordingly. Band fitting was done using a Lorentzian-Gaussian cross-product function with the minimum number of component bands used for the fitting process. The Gaussian-Lorentzian ratio was maintained at values greater than 0.7 and fitting was undertaken until reproducible results were obtained with squared correlations of $r^{2}$ greater than 0.995 .

\section{Results and discussion}

\section{Vibrational spectroscopy background}

In aqueous systems, the Raman spectra of phosphate oxyanions show a symmetric stretching mode $\left(v_{1}\right)$ at $938 \mathrm{~cm}^{-1}$, an antisymmetric stretching mode $\left(v_{3}\right)$ at $1017 \mathrm{~cm}^{-1}$, a symmetric bending mode $\left(v_{2}\right)$ at $420 \mathrm{~cm}^{-1}$ and a $v_{4}$ bending mode at $567 \mathrm{~cm}^{-1}$ [16-18]. S.D. Ross in Farmer [19] listed some well-known minerals containing phosphate which were either hydrated or hydroxylated or both [19]. However not all phosphate minerals were listed and there is a lack of information on anhydrous minerals. The vibrational spectrum of the dihydrogen phosphate anion has been reported by Farmer [19]. The $\mathrm{PO}_{2}$ symmetric stretching mode occurs at $1072 \mathrm{~cm}^{-1}$ and the $\mathrm{POH}$ symmetric stretching mode at $\sim 878 \mathrm{~cm}^{-1}$. The $\mathrm{POH}$ antisymmetric stretching mode was found at $947 \mathrm{~cm}^{-1}$ and the $\mathrm{P}(\mathrm{OH})_{2}$ bending mode at $380 \mathrm{~cm}^{-1}$. The band at $1150 \mathrm{~cm}^{-1}$ was assigned to the $\mathrm{PO}_{2}$ antisymmetric stretching mode. The position of these bands will shift according to the crystal structure of the mineral.

The vibrational spectra of phosphate minerals have been published by Farmer's treatise Chapter 17 [19]. The Table 17.III in Ref. [19] reports the band positions of a wide range of phosphates and arsenates, among other oxyanion minerals. The band positions for the monohydrogen phosphate anion of disodium hydrogen phosphate dihydrate is given as $v_{1}$ at 820 and $866 \mathrm{~cm}^{-1}, v_{2}$ at around $460 \mathrm{~cm}^{-1}, v_{3}$ as 953, 993, 1055, 1070, 1120 and $1135 \mathrm{~cm}^{-1}, v_{4}$ at $520,539,558,575 \mathrm{~cm}^{-1}$. The POH unit has vibrations associated with the $\mathrm{OH}$ specie. The stretching vibration of the $\mathrm{POH}$ units was tabulated as 2430 and $2870 \mathrm{~cm}^{-1}$, and bending modes at 766 and $1256 \mathrm{~cm}^{-1}$. Water stretching vibrations were found at 3050 and $3350 \mathrm{~cm}^{-1}$. The position of the bands for the disodium hydrogen phosphate is very dependent on the waters 
of hydration. There have been several Raman spectroscopic studies of the monosodium dihydrogen phosphate chemicals [20-24].

\section{Vibrational spectroscopy}

The Raman spectrum of whiteite in the $100-4000 \mathrm{~cm}^{-1}$ spectral range is illustrated in Fig. 1a. This Raman spectrum shows the position of the Raman bands and their relative intensities. It is obvious that there are large parts of the spectrum where little or no intensity is observed. Therefore, the spectrum is subdivided into sections according to the type of vibration being investigated. In this way, the precise position of the bands can be detailed. The infrared spectrum of whiteite in the $500-4000 \mathrm{~cm}^{-1}$ spectral range is shown in Fig. 1b. The reflectance spectrum starts at $\sim 500 \mathrm{~cm}^{-1}$ because the ATR cell absorbs all infrared radiation below this wavenumber. As for the Raman spectrum, the infrared spectrum is subdivided into sections depending upon the type of vibration being examined. The complete infrared spectrum displays the position of the infrared bands and their relative intensity. It is noted that there is significant intensity in the hydroxyl stretching region in both the Raman and infrared spectra.

The Raman spectrum of whiteite over the $900-1500 \mathrm{~cm}^{-1} \mathrm{spec}-$ tral range is illustrated in Fig. 2a. This spectral region is the region where the phosphate stretching modes are to be found. The spectrum is dominated by an intense sharp band at $972 \mathrm{~cm}^{-1}$. This band is assigned to the $\mathrm{PO}_{4}^{3-} v_{1}$ symmetric stretching vibration [8-12]. A low intensity shoulder band on the low wavenumber side of this band at $960 \mathrm{~cm}^{-1}$ is also found. A series of low intensity Raman bands at 1076 and $1173, \mathrm{~cm}^{-1}$ [8-14]. These bands are assigned to the $\mathrm{PO}_{4}^{3-} v_{3}$ antisymmetric stretching vibration. The Raman bands at 1266,1334 and $1368 \mathrm{~cm}^{-1}$ are assigned to $\mathrm{AlOH}$
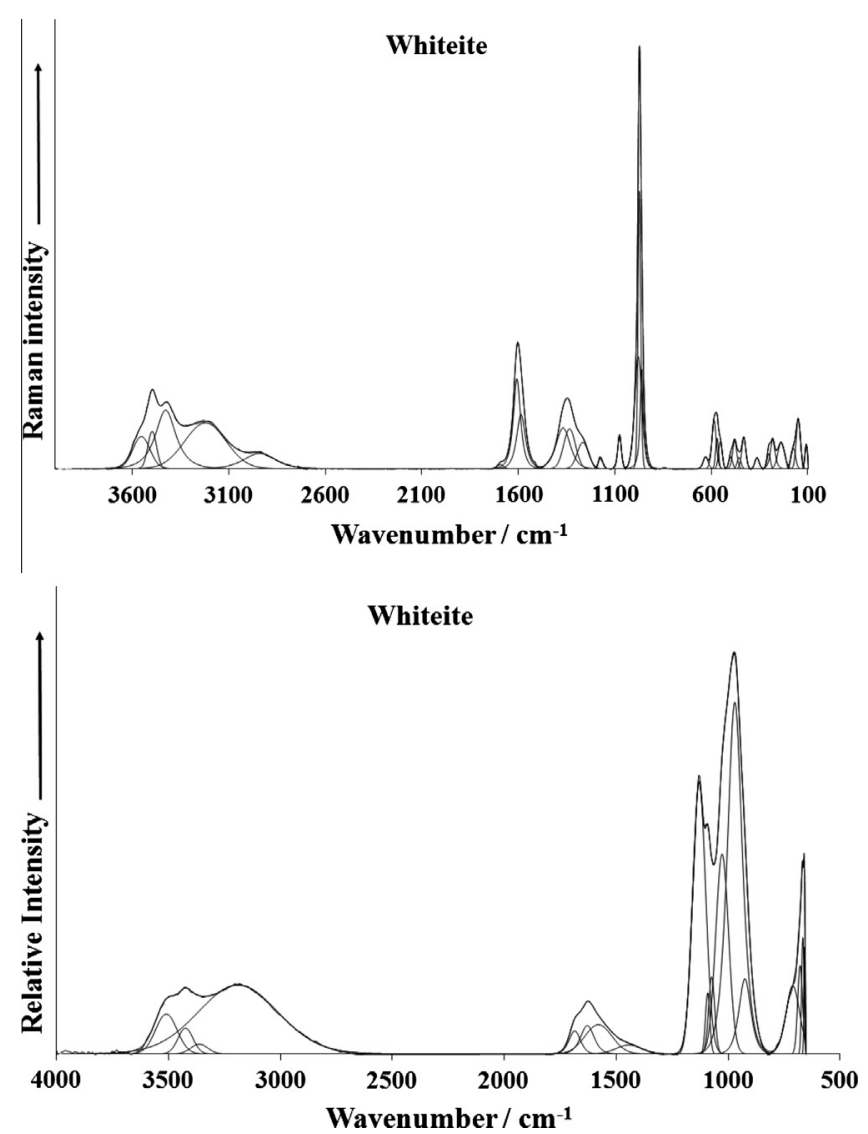

Fig. 1. (a) Raman spectrum of whiteite over the $100-4000 \mathrm{~cm}^{-1}$ spectral range (b) infrared spectra of whiteite over the $500-4000 \mathrm{~cm}^{-1}$ spectral range.
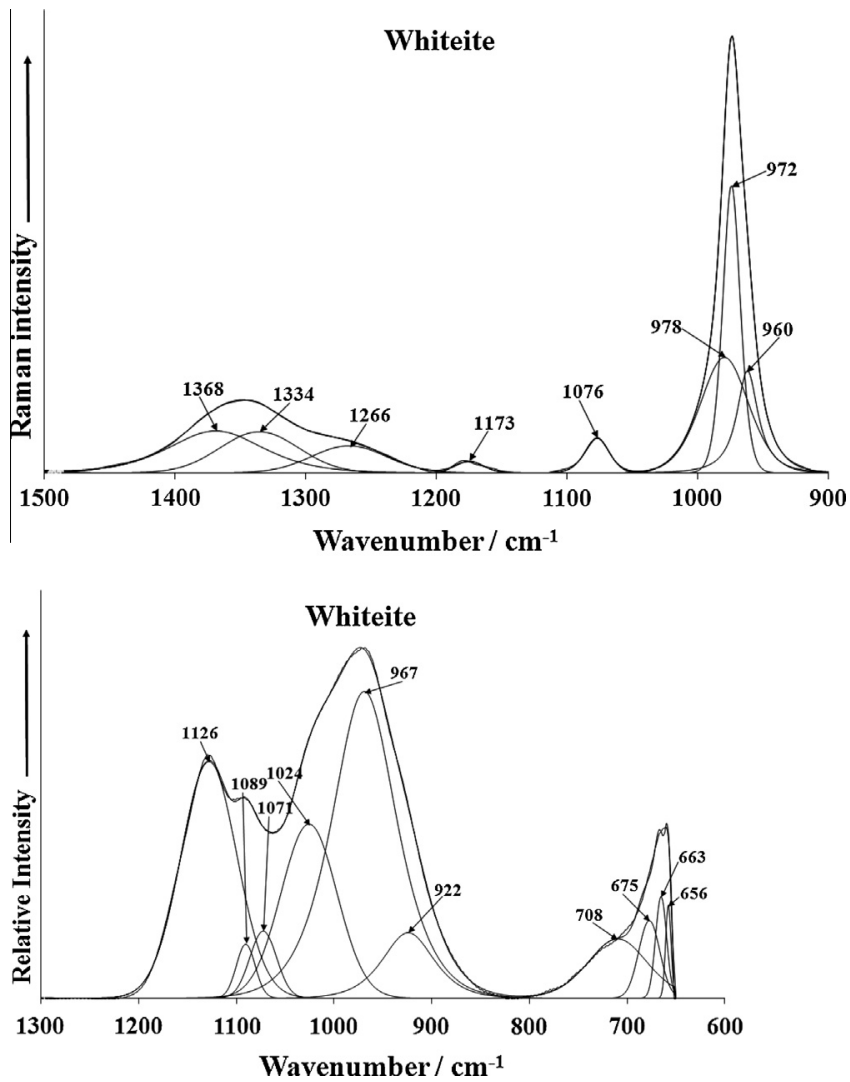

Fig. 2. (A) Raman spectrum of whiteite over the $900-1500 \mathrm{~cm}^{-1}$ range (b) Infrared spectrum of whiteite over the $600-1300 \mathrm{~cm}^{-1}$ range.

deformation modes [25]. The number of antisymmetric stretching modes provides evidence of reduced symmetry of the phosphate anion in the whiteite structure [8-12].

A comparison may be made with the spectroscopy of other phosphate minerals [8-14]. The Raman spectrum of wardite is dominated by two intense bands at around 995 and $1051 \mathrm{~cm}^{-1}$. These two bands are assigned to the $v_{1} \mathrm{PO}_{4}^{3-}$ symmetric stretching vibrations. Two intense bands are observed reflecting two nonequivalent phosphate units in the wardite structure. Breitinger et al. used FT-Raman to obtain their spectrum and found overlapping Raman bands at 999 and $1033 \mathrm{~cm}^{-1}$ and assigned these bands to the $v_{1} \mathrm{PO}_{4}^{3-}$ symmetric stretching and $v_{3} \mathrm{PO}_{4}^{3-}$ antisymmetric stretching modes. The difference in the spectra between our work and that of Breitinger et al., may be attributed to the improved technology of the spectrometer with greater resolution. Breitinger et al. also assigned the band at $999 \mathrm{~cm}^{-1}$ to $\mathrm{AlOH}$ deformation modes. In our work the Raman band at $995 \mathrm{~cm}^{-1}$ is very sharp and well resolved. The band at $1051 \mathrm{~cm}^{-1}$ is ever so slightly asymmetric on the low wavenumber side and a component may be resolved at $1045 \mathrm{~cm}^{-1}$. A group of low intensity bands are observed at $1083,1109,1140$ and $1186 \mathrm{~cm}^{-1}$ and are assigned to the $v_{3} \mathrm{PO}_{4}^{3-}$ antisymmetric stretching modes. Breitinger et al. did not report any bands in these positions in the Raman spectrum. These researchers reported infrared bands at 1058 (strong) with shoulders at 1129 and $1168 \mathrm{~cm}^{-1}$ and assigned these bands to $\delta \mathrm{Al}_{2} \mathrm{OH}$ deformation modes. A low intensity broad band at $884 \mathrm{~cm}^{-1}$ (a), $902 \mathrm{~cm}^{-1}$ (b) and $893 \mathrm{~cm}^{-1}$ (c) are assigned to a water librational mode. In the work of Breitinger et al., a broad low intensity band was found at around $800 \mathrm{~cm}^{-1}$ and was attributed to water librational modes.

The infrared spectrum over the $600-1300 \mathrm{~cm}^{-1}$ spectral range is provided in Fig. 2b. The infrared spectrum is broad; however 
some spectral features are observed which may be resolved into component bands as is illustrated in this figure. The band at $967 \mathrm{~cm}^{-1}$ is ascribed to the $\mathrm{PO}_{4}^{3-} v_{1}$ symmetric stretching vibrational mode [8-10]. The infrared bands at 1024, 1072, 1089 and $1126 \mathrm{~cm}^{-1}$ are attributed to the $\mathrm{PO}_{4}^{3-} v_{3}$ antisymmetric stretching vibrations [8-14]. The infrared bands at 922 and possibly the $708 \mathrm{~cm}^{-1}$ band are attributed to water librational modes. The infrared spectrum of wardite shows a great deal more complexity when compared with the Raman spectrum.

The infrared band at around $994 \mathrm{~cm}^{-1}$ is attributed to the $v_{1}$ $\mathrm{PO}_{4}^{3-}$ symmetric stretching mode. The cluster of bands at 1042 , $1053,1085,1102,1135$ and $1165 \mathrm{~cm}^{-1}$ are attributed to the $v_{3}$ $\mathrm{PO}_{4}^{3-}$ antisymmetric stretching modes. Some of these bands may also be due to the $\delta \mathrm{Al}_{2} \mathrm{OH}$ deformation modes, in harmony with the assignment of Breitinger et al. Breitinger and co-workers stated that the deceptively simple strong IR band centered at $1059 \mathrm{~cm}^{-1}$ contains at least four components of $v\left(\mathrm{PO}_{4}\right)$ generated by lifting of the originally threefold degeneracy of $v_{3}\left(\mathrm{PO}_{4}\right)$ and activation of $v_{1}\left(\mathrm{PO}_{4}\right)$ due to the general position of $\mathrm{PO}_{4}$ and again at least four components of the deformation modes $\delta\left(\mathrm{Al}_{2} \mathrm{OH}\right)$ involving the two pairs of the non-equivalent $\mathrm{OH}$ groups. In this work we have obtained much greater resolution and these components are resolved into the component bands.

The Raman spectrum of whiteite over the $300-700 \mathrm{~cm}^{-1}$ and $100-300 \mathrm{~cm}^{-1}$ spectral ranges are reported in Fig. 3 . The spectrum in Fig. 3a may be subdivided into sections. (a) the bands at around $586 \mathrm{~cm}^{-1}$ (b) the bands in the $432-500 \mathrm{~cm}^{-1}$ spectral range and (c) bands below $400 \mathrm{~cm}^{-1}$. In addition, there is a low intensity band at $630 \mathrm{~cm}^{-1}$. The Raman bands observed at 553, 571 and $586 \mathrm{~cm}^{-1}$ are assigned to the $v_{4}$ out of plane bending modes of the $\mathrm{PO}_{4}$ and possibly $\mathrm{H}_{2} \mathrm{PO}_{4}$ units. The Raman spectrum of $\mathrm{NaH}_{2} \mathrm{PO}_{4}$ shows bands at 526, 546 and $618 \mathrm{~cm}^{-1}$. The observation of multiple bands
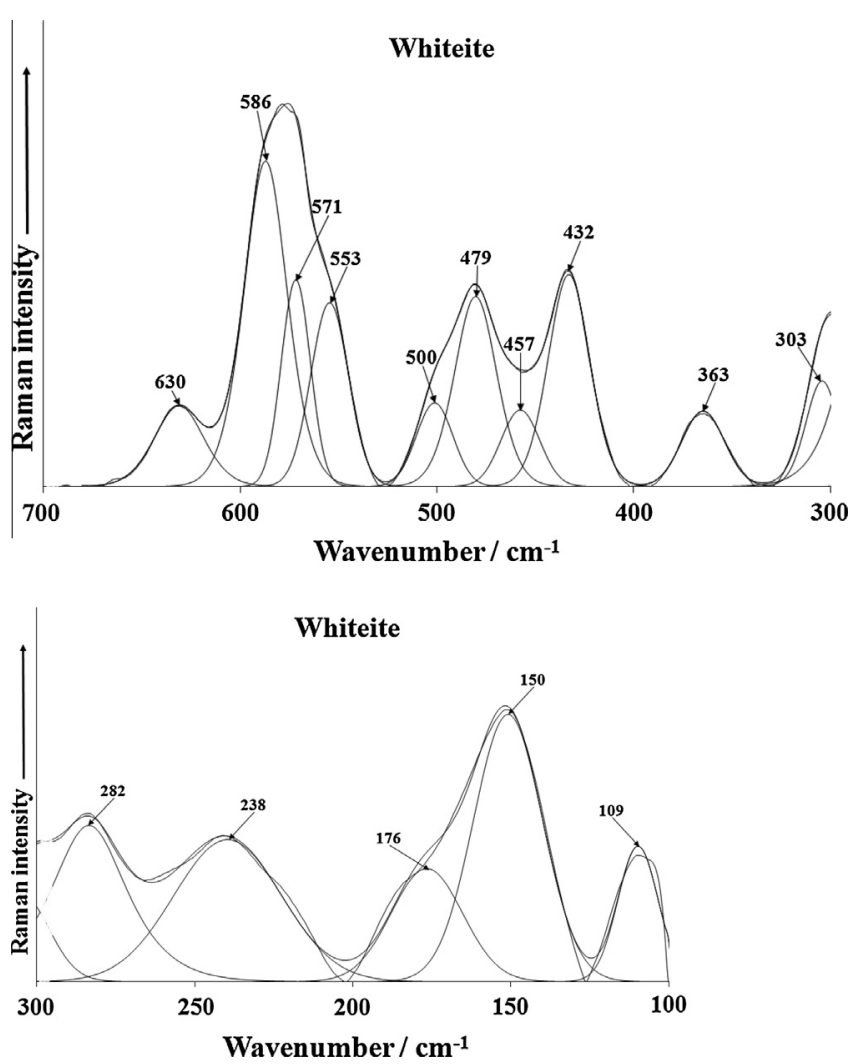

Fig. 3. (a) Raman spectrum of whiteite over the $300-700 \mathrm{~cm}^{-1}$ range (b) Raman spectrum of whiteite over the $100-300 \mathrm{~cm}^{-1}$ range. in this spectral region supports the concept of symmetry reduction of the phosphate. Intense Raman bands of wardite are observed at 588 and 620 with an additional band at $559 \mathrm{~cm}^{-1}$ are assigned to the $v_{4}$ out of plane bending modes of the $\mathrm{PO}_{4}^{3-}$ and $\mathrm{HOPO}_{3}^{2-}$ units. Breitinger et al. assigned these bands to $v\left(\mathrm{Al}(\mathrm{O} / \mathrm{OH})_{6}\right)$ stretching vibrations. No phosphate bending modes in the work of Breitinger et al. were reported. The Raman spectrum of crystalline $\mathrm{NaH}_{2} \mathrm{PO}_{4}$ shows Raman bands at 526, 546 and $618 \mathrm{~cm}^{-1}$ (data obtained by the authors).

Raman bands at 432, 457, 479 and $500 \mathrm{~cm}^{-1}$ are attributed to the $v_{2} \mathrm{PO}_{4}$ and $\mathrm{H}_{2} \mathrm{PO}_{4}$ bending modes. The Raman spectrum of $\mathrm{NaH}_{2} \mathrm{PO}_{4}$ shows two Raman bands at 460 and $482 \mathrm{~cm}^{-1}$. The observation of multiple Raman bands in this spectral region for the whiteite mineral supports the concept of symmetry reduction of the phosphate anion. A series of Raman bands for wardite are observed at 396, 416, 444, 464, and $489 \mathrm{~cm}^{-1}$. These bands are attributed to the $v_{2} \mathrm{PO}_{4}^{3-}$ and $\mathrm{H}_{2} \mathrm{PO}_{4}$ bending modes. The Raman spectrum of $\mathrm{NaH}_{2} \mathrm{PO}_{4}$ shows Raman bands at 460 and $482 \mathrm{~cm}^{-1}$. Thus, the series of Raman bands for wardite at 391, 401, 458, 485 and $510 \mathrm{~cm}^{-1}$ are attributed to the $v_{2} \mathrm{PO}_{4}^{3-}$ bending modes. Raman bands at 317,446 and $515 \mathrm{~cm}^{-1}$ reported by Breitinger et al. were assigned to vibrational modes of the $\mathrm{AlO}_{6} / \mathrm{AlOH}_{6}$ units. In the infrared spectrum of wardite, a series of infrared bands are observed at 620,643 and $673 \mathrm{~cm}^{-1}$. These bands are attributed to the $v_{4}$ out of plane bending modes of the $\mathrm{PO}_{4}^{3-}$ units. Breitinger et al. assigned bands in this region to $v\left(\mathrm{Al}(\mathrm{O} / \mathrm{OH})_{6}\right)$ stretching vibrations. In harmony with Breitinger et al. assignments, the infrared bands observed at 732, 795 and $893 \mathrm{~cm}^{-1}$ are attributed to water librational modes. Infrared bands observed at 573, 578 and $587 \mathrm{~cm}^{-1}$ are attributed to $\gamma\left(\mathrm{Al}_{2} \mathrm{OH}\right)$ vibrations.

Strong Raman bands are observed at 303 and $363 \mathrm{~cm}^{-1}$ with shoulder bands at 282 and $238 \mathrm{~cm}^{-1}$. These bands are assigned to
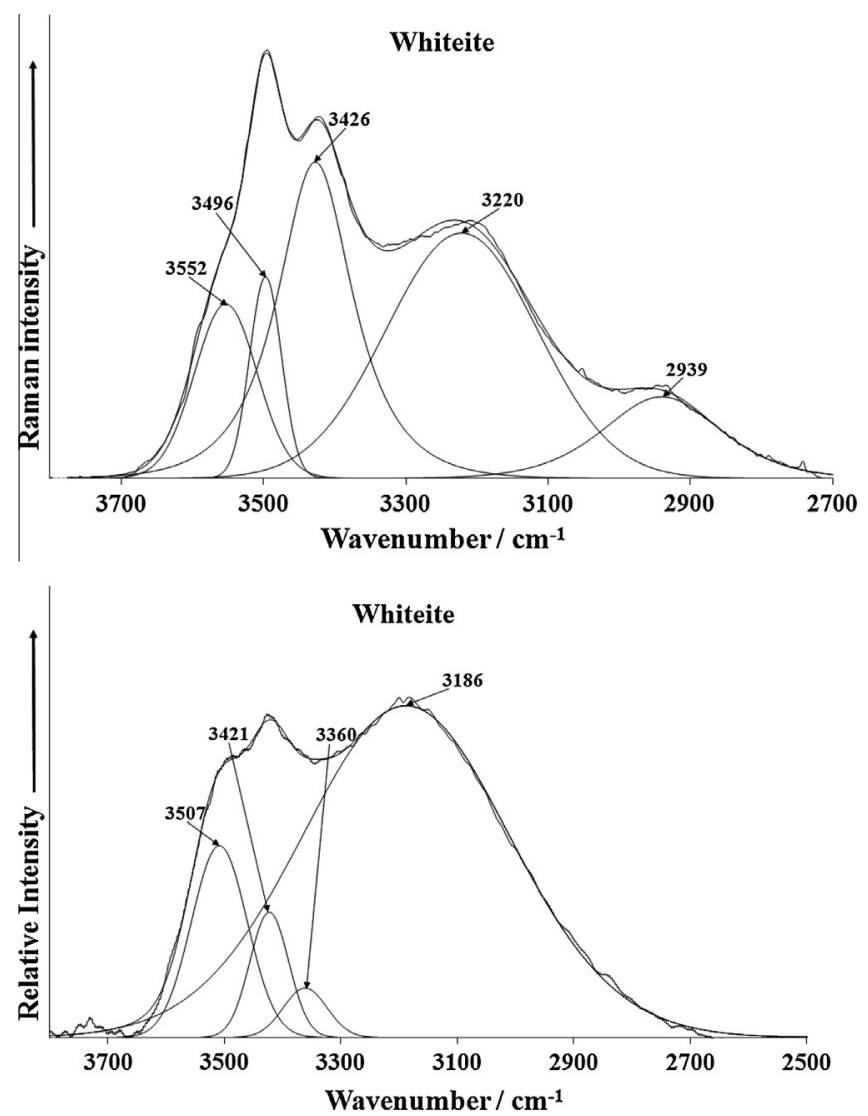

Fig. 4. (a) Raman spectrum of whiteite over the $2700-3800 \mathrm{~cm}^{-1}$ spectral range (b) Infrared spectrum of whiteite over the $2500-3800 \mathrm{~cm}^{-1}$ range. 
metal-oxygen stretching vibrations. Again, the observation of multiple bands in this spectral region supports the concept of the nonequivalence of phosphate units in the structure of whiteite. There are a number of bands in the Raman spectrum of the far low wavenumber region (Fig. 5b). These bands are ascribed to lattice vibrations. Intense Raman bands for wardite observed at $258 \mathrm{~cm}^{-1}$ and $299 \mathrm{~cm}^{-1}$ are related to the O-Al-O skeletal stretching vibrations. The intense band in all the spectra at $176 \mathrm{~cm}^{-1}$ is considered to be due to $\mathrm{H}-\mathrm{OH}$ hydrogen bonds. Other intense low wavenumber bands are observed for whiteite at 109 and $150 \mathrm{~cm}^{-1}$.

The Raman spectrum of whiteite over the $2700-3800 \mathrm{~cm}^{-1}$ spectral range is given in Fig. 4a. The infrared spectrum of whiteite over the $2500-3800 \mathrm{~cm}^{-1}$ spectral range is given in Fig. $4 \mathrm{~b}$. There are two features of the Raman spectrum in this spectral region: (a) the very broad feature centred upon around $3220 \mathrm{~cm}^{-1}$ and (b) the sharp bands at around $3496 \mathrm{~cm}^{-1}$. The three bands at 3426, 3496 and $3552 \mathrm{~cm}^{-1}$ are assigned to AlOH/AlF stretching vibrations. The broad feature may be resolved into component bands at 2939 and $3220 \mathrm{~cm}^{-1}$ and these bands are assigned to water stretching vibrations.

The infrared spectrum shows a band at $3421 \mathrm{~cm}^{-1}$ which may be assigned to the $\mathrm{OH}$ stretching vibration. As with the Raman spectrum, the broad feature centred around $3186 \mathrm{~cm}^{-1}$ may be resolved into component bands at 3186 and $3360 \mathrm{~cm}^{-1}$. These bands are assigned to water stretching vibrations. The infrared spectrum of wardite mineral samples display infrared bands at 3545 and $3611 \mathrm{~cm}^{-1}$ and are attributed to the $\mathrm{OH}$ stretching vibrations of the hydroxyl units. Two shoulder bands are observed at 3532 and $3601 \mathrm{~cm}^{-1}$ are also assigned to the $\mathrm{OH}$ stretching vibrations. A sharp band in the infrared spectrum is observed at $3480 \mathrm{~cm}^{-1}$ for some wardite samples. This band may be due to $\mathrm{FeOH}$ stretching vibrations. Breitinger et al. [25] found infrared bands
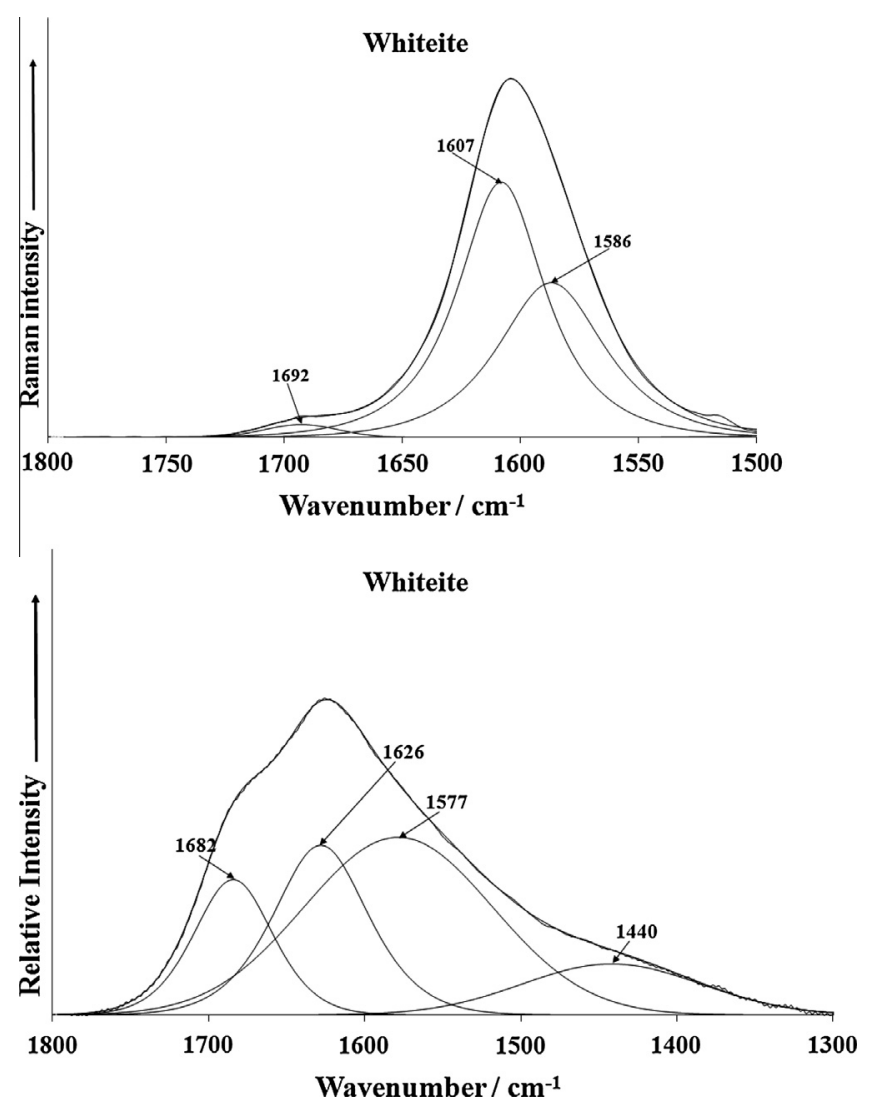

Fig. 5. (a) Raman spectrum of whiteite over the $1500-1800 \mathrm{~cm}^{-1}$ spectral range (b) Infrared spectrum of whiteite over the $1300-1800 \mathrm{~cm}^{-1}$ range. at $3520(\mathrm{vw}), 3545(\mathrm{~s}), 3585(\mathrm{sh})$ and $3613 \mathrm{~cm}^{-1}(\mathrm{~m})$. Breitinger et al. states that the $v(\mathrm{OH})$ modes in the two independent pairs of symmetry-correlated $\mathrm{OH}$ groups classify as $2 \mathrm{a}+2 \mathrm{~b}$; with the correlation splitting between a and $\mathrm{b}$ species depending on the distances in each of the pairs [25]. The $v(\mathrm{OH})$ region of IR spectra of wardite shows two sharp bands ( 3613 and $3545 \mathrm{~cm}^{-1}$ ) with two weak shoulders or satellites ( 3580 and $3520 \mathrm{~cm}^{-1}$ ). It is likely that the two sharp infrared bands are due to two independent and nonequivalent $\mathrm{OH}$ units. The two sharp shoulder bands may be attributed to the Al-OH-Fe groups, i.e. the cyrilovite part of the solid solution. Broad infrared bands for wardite are observed at 2876 and $3266 \mathrm{~cm}^{-1}$. These bands are assigned to water stretching vibrations. It is probable that some of the component bands are due to overtones and combination of the water bending and librational modes. The position of the water stretching vibration provides evidence for strong hydrogen bonding and that water is involved in different hydrogen bonding arrangements. The band at around $2876 \mathrm{~cm}^{-1}$ gives an indication that water is very strongly hydrogen bonded in the wardite structure.

The Raman spectrum of whiteite in the $1500-1800 \mathrm{~cm}^{-1} \mathrm{spec}-$ tral range is reported in Fig. 5a. The infrared spectrum of whiteite in the $1300-1800 \mathrm{~cm}^{-1}$ spectral range is reported in Fig. 5b. The Raman spectrum displays an intensity Raman band at $1607 \mathrm{~cm}^{-1}$ which is assigned to the water bending mode. This band is also observed in the infrared spectrum at $1626 \mathrm{~cm}^{-1}$. This band is indicative of very weakly hydrogen bonded water. The infrared band at $1682 \mathrm{~cm}^{-1}$ together with the Raman band at $1692 \mathrm{~cm}^{-1}$ are attributed to more strongly hydrogen bonded water. The infrared bands at 1440 and $1577 \mathrm{~cm}^{-1}$ may be an overtone or combination band.

\section{Conclusions}

Whiteite is a hydrated hydroxyl multi cation phosphate of magnesium and aluminum CaMn ${ }^{++} \mathrm{Mg}_{2} \mathrm{Al}_{2}\left(\mathrm{PO}_{4}\right)_{4}(\mathrm{OH})_{2} \cdot 8\left(\mathrm{H}_{2} \mathrm{O}\right)$. The mineral is chemically related to wardite.

Raman spectroscopy complimented with infrared spectroscopy has been used to study aspects of the molecular structure of this phosphate mineral whiteite. The structure of whiteite is monoclinic. As a consequence multiple phosphate vibrational modes are observed. Raman and infrared bands are observed and attributed to phosphate, hydroxyl and water vibrational stretching and bending modes. The structure of wardite contains layers of corner-linked - $\mathrm{OH}$ bridged $\mathrm{MO}_{6}$ octahedra stacked along the tetragonal $\mathrm{C}$-axis in a four-layer sequence and linked by $\mathrm{PO}_{4}$ groups. As a consequence at the molecular level non-equivalent phosphate units exist in the structure of whiteite. As a consequence multiple phosphate vibrational modes are observed.

\section{Acknowledgments}

The financial and infra-structure support of the Queensland University of Technology, Chemistry discipline is gratefully acknowledged. The Australian Research Council (ARC) is thanked for funding the instrumentation. The authors would like to acknowledge the Center of Microscopy at the Universidade Federal de Minas Gerais (http://www.microscopia.ufmg.br) for providing the equipment and technical support for experiments involving electron microscopy. R. Scholz thanks to CNPq - Conselho Nacional de Desenvolvimento Científico e Tecnológico (Grant Nos. 306287/ 2012-9 and 402852/2012-5 ).

\section{References}

[1] M. Fleischer, G.Y. Chao, A. Pabst, Amer. Min. 64 (1979) 464-467.

[2] A.R. Kampf, I.M. Steele, T.A. Loomis, Amer. Min. 93 (2008) 940-945.

[3] M. Baijot, F. Hatert, S. Philippo, Can. Min. 50 (2012) 1531-1554. 
[4] P.B. Moore, J. Ito, I. Whiteite, Min. Mag. 42 (1978) 309-323.

[5] I.E. Grey, W.G. Mumme, S.M. Neville, N.C. Wilson, W.D. Birch, Min. Mag. 74 (2010) 969-978.

[6] G.W. Robinson, J. Van Velthuizen, H.G. Ansell, B.D. Sturman, Min. Rec. 23 1992) 1-47.

[7] R. Simeone, Riv. Min. Ital. (1980) 52-56.

[8] R.L. Frost, Y. Xi, R. Scholz, M. Belotti Fernanda, Spectrochim. Acta A103 (2013) $143-150$.

[9] R.L. Frost, Y. Xi, R. Scholz, M. Belotti Fernanda, A. Dias Menezes Filho Luiz, Spectrochim. Acta A104 (2013) 250-256.

[10] R.L. Frost, A. Lopez, Y. Xi, A. Granja, R. Scholz, R.M.F. Lima, Spectrochim. Acta A114 (2013) 309-315

[11] R.L. Frost, Y. Xi, M. Beganovic, F.M. Belotti, R. Scholz, Spectrochim. Acta A107 (2013) 241-247.

12] R.L. Frost, Y. Xi, R. Scholz, Spectrochim. Acta A108 (2013) 244-250.

[13] R.L. Frost, Y. Xi, R. Scholz, F.M. Belotti, Spectrochim. Acta A105 (2013) 359-364.

[14] R.L. Frost, Y. Xi, R. Scholz, F.M. Belotti, M. Beganovic, Spectrochim. Acta A110 (2013) 7-13.

[15] J.W. Anthony, R.A. Bideaux, K.W. Bladh, M.C. Nichols, Handbook of Mineralogy, Mineral Data Publishing, Tuscon, Arizona, USA, 1995.
[16] R.L. Frost, W. Martens, P.A. Williams, J.T. Kloprogge, Min. Mag. 66 (2002) $1063-$ 1073.

[17] R.L. Frost, W.N. Martens, T. Kloprogge, P.A. Williams, Neues Jahr. Min. Mh. (2002) 481-496.

[18] R.L. Frost, P.A. Williams, W. Martens, J.T. Kloprogge, P. Leverett, J. Raman Spectrosc. 33 (2002) 260-263.

[19] V.C. Farmer, Mineralogical Society Monograph 4: The Infrared Spectra of Minerals, London, 1974

[20] C.E. Bamberger, W.R. Busing, G.M. Begun, R.G. Haire, L.C. Ellingboe, J. Solid State Chem. 57 (1985) 248-259.

[21] B.K. Choi, M.N. Lee, J.J. Kim, J. Raman Spectrosc. 20 (1989) 11-15.

[22] A. Galy, J. Phys. Rad. 12 (1951) 827.

[23] H. Poulet, N. Toupry-Krauzman, Proc. Int. Conf. Raman, Spectrosc., 6th, 2 (1978) 364-365.

[24] N. Toupry-Krauzman, H. Poulet, M. Le Postollec, J. Raman Spectrosc. 8 (1979) $115-121$.

[25] D.K. Breitinger, H.H. Belz, L. Hajba, V. Komlosi, J. Mink, G. Brehm, D. Colognesi, S.F. Parker, R.G. Schwab, J. Mol. Struct. 706 (2004) 95-99. 